\title{
Melittin, a Potential Natural Toxin of Crude Bee Venom: Probable Future Arsenal in the Treatment of Diabetes Mellitus
}

\author{
Md. Sakib Hossen, ${ }^{1}$ Siew Hua Gan, ${ }^{2}$ and Md. Ibrahim Khalil ${ }^{1,2}$ \\ ${ }^{1}$ Laboratory of Preventive and Integrative Biomedicine, Department of Biochemistry and Molecular Biology, \\ Jahangirnagar University, Savar, Dhaka 1342, Bangladesh \\ ${ }^{2}$ Human Genome Centre, School of Medical Sciences, Universiti Sains Malaysia, 16150 Kubang Kerian, Kelantan, Malaysia \\ Correspondence should be addressed to Siew Hua Gan; shgan@usm.my and Md. Ibrahim Khalil; drmikhalil@gmail.com
}

Received 29 March 2017; Revised 8 June 2017; Accepted 14 June 2017; Published 12 July 2017

Academic Editor: Sevgi Kolaylı

Copyright (C) $2017 \mathrm{Md}$. Sakib Hossen et al. This is an open access article distributed under the Creative Commons Attribution License, which permits unrestricted use, distribution, and reproduction in any medium, provided the original work is properly cited.

\begin{abstract}
Since diabetes mellitus (DM) is one of the most common and serious endocrine metabolic disorders, it is important to elucidate novel antidiabetic therapeutic agents from various sources, including natural products. Bee venom (BV) is a complex mixture of proteins, peptides, and low molecular components, and melittin is the main constituent. Melittin is a peptide consisting of 26 amino acids with the sequence GIGAVLKVLTTGLPALISWIKRKRQQ. It has several important biological effects and has a relatively low toxicity. Recent studies using animal models have confirmed that melittin has significant glucose and lipid lowering activities by acting on several mechanistic pathways. The main antidiabetic activity of melittin is increasing insulin secretion via depolarization of pancreatic $\beta$-cells. Other possible mechanisms may involve stimulation of phospholipase $A_{2}$, increase of glucose uptake, improving lipid profile, and/or reduction of inflammation. This review summarizes the various sources, proteomics, biological roles, adverse effects, and medical applications of melittin and its mechanism of action in combating DM.
\end{abstract}

\section{Introduction}

Diabetes mellitus (DM) is a serious disease in which the body cannot control the amount of sugar in circulation due to either a deficiency of insulin secretion or a decreased sensitivity of the tissues to insulin. There are two main types of diabetes as follows: Type 1 and Type 2 [1]. Both types can cause serious health complications, including kidney failure, heart disease, blurred vision, ketoacidosis, peripheral neuropathy, itchiness, fatigue, and even coma [2]. An insulin deficiency leads to elevations of cholesterol, phospholipids, and free fatty acids [3]. Therefore, it is important that an ideal DM therapy should not only involve maintaining blood glucose levels but also involve the regulation of the lipid profile.

To treat DM, several antidiabetic drugs are used. However, these drugs are not without side effects and pose an economic burden to the patient. Therefore, scientists have turned to natural remedies, including honey and bee products, such as bee venom (BV). BV is a complex mixture of proteins, peptides, and low molecular components secreted by the worker and the queen bees. The main active constituent of BV (apitoxin) is melittin, which has a relatively low toxicity [4]. It exerts important effects on cells, such as hemolysis, membrane depolarization and muscle contraction, cytotoxicity, and phospholipase $\mathrm{C}$ and arachidonic acid following phospholipase $\mathrm{A} 2$ activation. In addition, it is also responsible for various allergic reactions in the body and can suppress the signal pathways of toll-like receptors (TLR2, TLR4), cluster of differentiation (CD14), nuclear factor kappa-B essential modulator (NEMO), and platelet-derived growth factor beta (PDGFR $\beta)$. By suppressing these pathways, melittin diminishes the activation of $\mathrm{p} 38, \mathrm{ERK} 1 / 2, \mathrm{AKT}$, and PLC $\gamma 1$ and the translocation of NF- $\kappa \mathrm{B}$ into the nucleus, consequently leading to reduced inflammation in the skin, aorta, joints, liver, and neuronal tissues [5].

BV proteins, mainly melittin, are also widely used in the treatment of arthritis, frozen shoulder, diseases of the central and peripheral nervous system (CNS, PNS), skin diseases, heart and blood system related diseases, cancer, ulcer, colitis, 


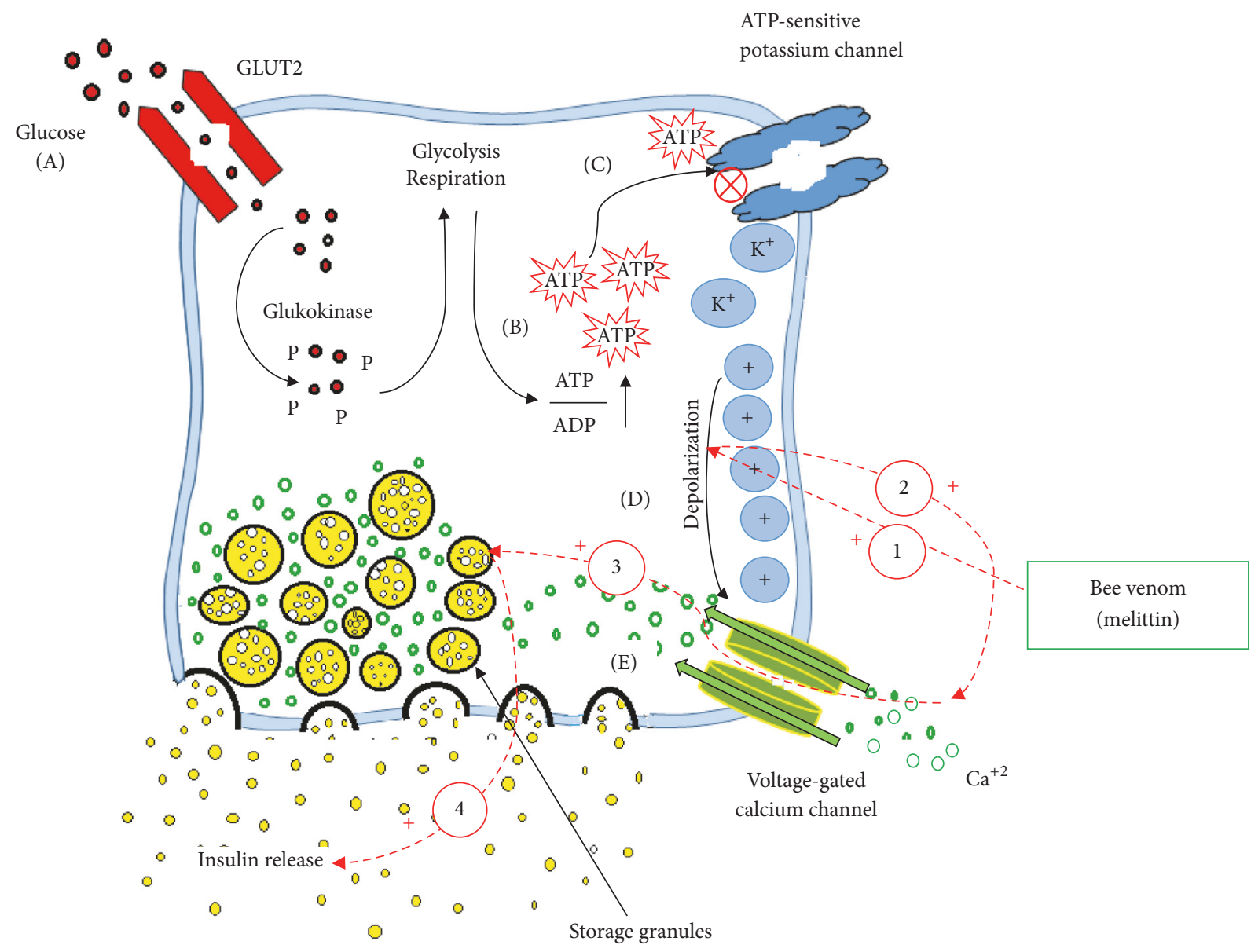

FIGURE 1: Basic mechanism of insulin secretion and sequential mechanistic pathway of BV (melittin) leading to an increase in insulin secretion in pancreatic $\beta$-cells. (A) Blood glucose ( $>5 \mathrm{mM}$ in concentration) enters the $\beta$-cell through the glucose transporter (GLUT2). (B) ATP production rapidly occurs as a result of glycolysis and respiration. (C) Then, ATP-sensitive $\mathrm{K}^{+}$channels are closed, and $\mathrm{K}^{+}$efflux is inhibited. (D) Consequently, plasma membrane depolarizes, and (E) voltage-gated $\mathrm{Ca}^{2+}$ channels open. Finally, $\mathrm{Ca}^{2+}$ influx increases, which triggers exocytosis of insulin granules. (1) Melittin directly depolarizes the cell membrane, (2) it increases $\mathrm{Ca}^{2+}$ inflow into the cell, (3) it promotes more granule secretion, and (4) it increases insulin secretion into the blood stream. Note: phosphorus: P; calcium: Ca ${ }^{2+}$. Adapted from https://www.dolcera.com/wiki/index.php?title=Diabetes_products_and_services.

and neuritis $[14,15,17,19,24-28]$. Recent studies also confirmed that melittin can significantly reduce blood glucose via insulin secretion and glucose uptake in animal models [2123]. These studies also reported that melittin has significant lipid regulating activities by activating phospholipase $A_{2}$. Thus, melittin could be a potential therapeutic agent against DM.

A number of reviews are available in the literature, which focused on the miscellaneous pharmacological effects of BV proteins [17, 29-37]. However, to date, reviews of the mechanisms by which BV contributes to the antidiabetic activity are currently not available. In this review, we discussed the principal activity of melittin (Table 1) and its antidiabetic mechanism of actions (Figure 1).

\section{Composition of Honeybee Venom}

$\mathrm{BV}$ is a bitter colorless liquid ( $\mathrm{pH} 4.5-5.5)$ that dries up easily even at room temperature and is soluble in water but insoluble in alcohol and ammonium sulfate $[5,38,39]$. A bee can inject up to $0.1 \mathrm{mg}$ venom via its stinger. It has been reported to be similar to the toxin of the sea nettle [40]. The venom is mainly produced in the abdomen of the worker bees and originates from a mixture of acidic and basic secretions. It is a complex mixture of proteins, in which some enzymes (catalyzing specific reactions), some peptides (which consist of two or more amino acids), and others, including a variety of low molecular components, such as carbohydrates $(2 \%$ of venom dry weight), phospholipids (5\% of venom dry weight), amino acids (1\% of venom dry weight), minerals (3$4 \%$ of venom dry weight), and volatile compounds (5-8\% of venom dry weight) [15, 41], are present. Among these, the main component comprises proteins and peptides, the combination of which is commonly known as venom toxins.

\section{Melittin}

In a previous study, Danneels et al. determined the constituents of 34 samples of venom toxins by using mass spectrometry [42]. Among all of the honey proteins, the 
TABLE 1: Principal honeybee protein (melittin).

\begin{tabular}{|c|c|}
\hline Bee venom protein name & Melittin \\
\hline Alternative names & Allergen Api m 3, Allergen Api m III, Allergen Api m 4 \\
\hline Percentage of dry weight (\%) & $40-50$ \\
\hline \multicolumn{2}{|l|}{ Sources } \\
\hline Honeybee & $\begin{array}{l}\text { Apis mellifera (honeybee), Apis mellifera carnica (Carniolan honeybee), Apis dorsata } \\
\text { (giant honeybee), Apis florea (dwarf honeybee), Apis cerana (Indian honeybee) }\end{array}$ \\
\hline Bee & Osmia rufa (red mason bee) \\
\hline Insect & $\begin{array}{l}\text { Vespa magnifica (hornet), Polistes hebraeus (paper wasp), Polistes sp. (golden paper } \\
\text { wasp), Vespula maculifrons (eastern yellow jacket), Vespa velutina nigrithorax } \\
\text { (hornet) }\end{array}$ \\
\hline Bacteria & $\begin{array}{l}\text { Salmonella typhi, Pseudomonas fluorescens, Synechocystis sp., Aphanocapsa sp., } \\
\text { Escherichia coli, Stenotrophomonas maltophilia, Pseudomonas maltophilia, } \\
\text { Xanthomonas maltophilia, Moellerella wisconsensis, Pseudomonas batumici, } \\
\text { Ralstonia solanacearum, Thioalkalivibrio nitratireducens, Klebsiella pneumonia, } \\
\text { Francisella sp., Brucella melitensis biotype 1, Ralstonia solanacearum, Bacteroides } \\
\text { xylanisolvens, Acinetobacter baumannii, Acinetobacter bereziniae, Sporomusa sp., } \\
\text { Zunongwangia profunda, Leeuwenhoekiella blandensis, Cyclobacterium qasimii } \\
\text { M12-11b }\end{array}$ \\
\hline Others & $\begin{array}{l}\text { Rana arvalis (moor frog), Rana temporaria (European common frog), Rana tagoi } \\
\text { (Tago frog), Rana tagoi okiensis (Oki brown frog), Rana sakuraii (Japanese brown } \\
\text { frog), Naja oxiana (Central Asian Cobra) (Oxus cobra), Pardachirus pavoninus } \\
\text { (peacock sole) }\end{array}$ \\
\hline Tissue specificity & Expressed by the venom gland \\
\hline Gene name & MELT \\
\hline Formula & $\mathrm{C}_{350} \mathrm{H}_{552} \mathrm{~N}_{84} \mathrm{O}_{99} \mathrm{~S}_{2}$ \\
\hline Total number of atoms & 1087 \\
\hline Molecular weight (Dalton) & 7584.8 \\
\hline Total length (amino acids) & 70 \\
\hline Peptide length (amino acids) & 26 \\
\hline Total sequence & $\begin{array}{l}\text { 10: MKFLVNVALV, 20: FMVVYISYIY, 30: AAPEPEPAPE, 40: PEAEADAEAD, 50: } \\
\text { PEAGIGAVLK, 60: VLTTGLPALI, 70: SWIKRKRQQG }\end{array}$ \\
\hline Peptide sequence & 44-69: GIGAVLKVLTTGLPALISWIKRKRQQ \\
\hline Theoretical isoelectric point $(\mathrm{pI})$ & 4.69 \\
\hline Subunit & Monomer and homotetramer \\
\hline $\begin{array}{l}\text { Total number of negatively } \\
\text { charged residues (Asp + Glu) }\end{array}$ & 9 \\
\hline $\begin{array}{l}\text { Total number of positively } \\
\text { charged residues (Arg + Lys) }\end{array}$ & 6 \\
\hline $\begin{array}{l}\text { Extinction coefficient } \\
\left(\mathrm{M}^{-1} \mathrm{~cm}^{-1}\right)\end{array}$ & 9970 , at $280 \mathrm{~nm}$ measured in water \\
\hline Estimated half-life & $\begin{array}{l}\text { (i) } 30 \text { hours (mammalian reticulocytes, in vitro) } \\
\text { (ii) }>20 \text { hours (yeast, in vivo) } \\
\text { (iii) }>10 \text { hours (Escherichia coli, in vivo) }\end{array}$ \\
\hline $\begin{array}{l}\text { Grand average of hydropathicity } \\
\text { (GRAVY) }\end{array}$ & 0.239 \\
\hline Toxic dose & $\mathrm{LC}(50)$ is $2.7 \mu \mathrm{g} / \mathrm{mL}$ against killifish \\
\hline \multicolumn{2}{|l|}{ Investigated biological functions } \\
\hline Major & $\begin{array}{l}\text { (i) Hemolytic activity } \\
\text { (ii) Anti-inflammatory activity } \\
\text { (iii) Anticancer, antibacterial, antifungal, antiviral activities }\end{array}$ \\
\hline
\end{tabular}


TABle 1: Continued.

\begin{tabular}{|c|c|}
\hline Others & $\begin{array}{l}\text { (i) Inhibits well-known transport pumps (such as } \mathrm{Na}^{+}-\mathrm{K}^{+} \text {-ATPase, } \mathrm{H}^{+}-\mathrm{K}^{+} \text {-ATPase) } \\
\text { (ii) Activates phospholipase } \mathrm{A}_{2} \\
\text { (iii) Diminishes membrane surface tension } \\
\text { (iv) Stimulates smooth muscle } \\
\text { (v) Lowers blood coagulation } \\
\text { (vi) Influences central nervous system (CNS) } \\
\text { (vii) Increases capillary permeability }\end{array}$ \\
\hline Adverse effects & $\begin{array}{l}\text { (i) Initiates various allergic reactions } \\
\text { (ii) Lyses erythrocytes } \\
\text { (iii) Creates cytotoxicity in human peripheral blood lymphocytes } \\
\text { (iv) Modulates gene expression related to apoptosis, DNA damage response, and } \\
\text { oxidative stress }\end{array}$ \\
\hline Medical applications & $\begin{array}{l}\text { (i) Arthritis } \\
\text { (ii) Cancer } \\
\text { (iii) Diseases of central and peripheral nervous systems } \\
\text { (iv) Skin diseases } \\
\text { (v) Heart and blood system related diseases } \\
\text { (vi) Frozen shoulder } \\
\text { (vii) Asthma, bronchitis } \\
\text { (viii) Colitis, ulcers } \\
\text { (xi) Others: ophthalmology, endocrinology, urology, gynecology, } \\
\text { otorhinolaryngology }\end{array}$ \\
\hline Data sources and references & $\begin{array}{l}\text { (i) Research Collaboratory for Structural Bioinformatics, Protein Data Bank (RCSB } \\
\text { PDB) } \\
\text { (ii) Protein Information Resource (PIR) } \\
\text { (iii) UniprotKB } \\
\text { (iv) [5-19] }\end{array}$ \\
\hline
\end{tabular}

Note. Lethal concentration: LC, three-dimensional: 3D, and nuclear magnetic resonance: NMR.

principal protein is confirmed to be melittin, which constitutes approximately $40-50 \%$ of the venom dry weight [15]. Melittin consists mainly of a 26-amino-acid peptide with no disulfide bridge in which the N-terminal part of the molecule is predominantly hydrophobic while the C-terminal is hydrophilic and is strongly basic [PMID: 10692322]. The characteristics of melittin, including the sources, proteomics, biological functions, adverse effects, and medical applications, are summarized in Table 1.

\section{Previous Breakthroughs of Bee Venom's Role in Diabetes}

Several epidemiological studies using animal models have shown that the use of BV is associated with a lower DM risk (Table 2). Kim et al. investigated whether BV can prevent insulitis and the development of diabetes in nonobese diabetic (NOD) female mice that have been subdivided into control $(n=24)$ and BV $(n=24)$ treated groups [20]. BV (purchased from Sigma, MO, USA) was injected at $0.5 \mathrm{mg} / \mathrm{kg}$ into the hind limb twice per week when the mice were between 4 and 10 weeks of age. The cumulative incidences of diabetes in the control and BV treated NOD mice were $58 \%$ and $21 \%$, respectively, at 25 weeks of age. Therefore, it was postulated that BV treatment in NOD mice inhibits insulitis and the onset and overall incidence of diabetes at an early age.

Another in vivo study conducted by Mousavi et al. reported that Iranian BV (Apis mellifera) can lower blood glucose and lipid levels in diabetic rats [21]. Adult male rats ( $n=18)$ weighing $200 \pm 20 \mathrm{~g}$ were placed into the following three random groups: control rats, alloxan monohydratedinduced diabetic rats (150 mg/kg intraperitoneally), and BV treated rats $(0.5 \mathrm{mg} / \mathrm{kg})$. In their experiment, BV was collected from beehives using an electric shocker.

In addition to Apis mellifera BV, BV from Apis cerana has also been reported to have antidiabetic activity as reported by Prakash and Bhargava [22]. In their study, the samples were divided into test and control groups in which the test group was categorized as "before" and "after" being stung by Apis cerana bees. Their study also reported that Apis cerana $B V$ reduced blood cholesterol and triglyceride levels. Then, Khulan AM and Chimedragcha [23] investigated the effects of Mongolian BV on hyperglycemia and hyperlipidemia in alloxan-induced diabetic rabbits [23]. For this study, chinchilla rabbits $(n=22)$ were divided into the following three groups: control $(n=6)$, diabetic $(n=8)$, and BV treated $(n=8)$ groups. To induce diabetes, an alloxan monohydrated solution (5\%) was administered at $100 \mathrm{mg} / \mathrm{kg}$ intravenously via the marginal vein behind the ear over two minutes. Meanwhile, the BV treated group received a bee sting on their hind paw every other day following the confirmation of diabetes. Their results also supported that BV significantly lowers serum glucose levels and improves the lipid profile. All of the researchers confirmed that the principal protein in $\mathrm{BV}$, melittin, is mainly responsible for the antidiabetic actions, which was also confirmed by an in vitro test that indicated 
TABLE 2: In vivo studies of DM based on BV.

\begin{tabular}{|c|c|c|c|c|c|}
\hline $\begin{array}{l}\text { Venom } \\
\text { source }\end{array}$ & $\begin{array}{c}\text { Animal } \\
\text { model }\end{array}$ & Duration & Dose & Outcomes & $\begin{array}{c}\text { Year, } \\
\text { reference }\end{array}$ \\
\hline $\begin{array}{l}\text { BV from } \\
\text { Sigma, } \\
\text { MO, USA }\end{array}$ & Mice & 25 weeks & $0.5 \mathrm{mg} / \mathrm{kg}$ & $\begin{array}{l}\text { (i) Inhibited insulitis } \\
\text { (ii) Inhibited onset and } \\
\text { cumulative incidence of diabetes }\end{array}$ & 1999 [20] \\
\hline $\begin{array}{l}\text { Iranian } \\
\text { Honey BV } \\
\text { (Apis } \\
\text { mellifera) }\end{array}$ & Lewis rats & 4 months & $0.5 \mathrm{mg} / \mathrm{kg}$ & $\begin{array}{l}\text { (i) Increased serum insulin level } \\
\text { (ii) Decreased serum triglyceride } \\
\text { contents } \\
\text { (iii) Decreased serum total } \\
\text { cholesterol }\end{array}$ & 2012 [21] \\
\hline $\begin{array}{l}\text { Apis } \\
\text { cerana BV }\end{array}$ & Human & $\begin{array}{c}\approx 30 \\
\text { minutes }\end{array}$ & $\begin{array}{c}\text { Apis cerana bees } \\
(n=8) \text { sting the } \\
\text { groups } \\
\text { individually }\end{array}$ & $\begin{array}{l}\text { (i) Decreased blood sugar } \\
\text { (ii) Decreased blood cholesterol } \\
\text { (iii) Decreased blood triglyceride } \\
\text { contents } \\
\text { (iv) Increased eosinophil count }\end{array}$ & 2014 [22] \\
\hline $\begin{array}{l}\text { Mongolian } \\
\text { BV (Apis } \\
\text { mellifera) }\end{array}$ & Rabbits & 14 days & $\begin{array}{l}\text { A bee sting } \\
\text { (contains } \\
0.2-0.5 \mathrm{~mL} \text { of } \\
\mathrm{BV})\end{array}$ & $\begin{array}{l}\text { (i) Decreased blood glucose } \\
\text { levels } \\
\text { (ii) Decreased blood cholesterol } \\
\text { levels } \\
\text { (iii) Decreased low density } \\
\text { lipoproteins } \\
\text { (iv) Increased high density } \\
\text { lipoproteins }\end{array}$ & 2015 [23] \\
\hline
\end{tabular}

that melittin can increase insulin secretion from pancreatic $\beta$-cells.

\section{Antidiabetic Mechanism of Actions of Melittin}

DM is a syndrome of impaired carbohydrate, fat, and protein metabolisms due to a combination of both hereditary and environmental causes and is characterized by increased blood glucose levels. In DM therapy, great attention is paid to lowering blood glucose levels by increasing insulin secretion and lipid regulating mechanisms of various medical agents, including those from animal toxins. Melittin reduces blood glucose levels by increasing insulin secretion from the $\beta$-cells of the pancreas and facilitating glucose uptake [43]. It also alleviates complications of DM by ameliorating lipid profiles as verified by several studies [21-23].

Recent studies reported that various types of BV significantly reduce not only blood glucose levels but also total cholesterol (Table 2). Melittin, which is present in BV, is mainly responsible for the antidiabetic role as confirmed by an in vitro test conducted by Morgan and Montague [43]. Melittin reduces blood glucose levels by several different mechanisms, including depolarization of $\beta$-cell membranes, increasing the extracellular calcium and calcium channels [21, $44]$, activating cytosolic phospholipase A2 [23, 45], increasing glucose transporter lipid uptake into adipose tissues [23], and suppression of $\beta$-cell inflammation [46].

Melittin initiates membrane depolarization to cause closure of the ATP-sensitive $\mathrm{K}^{+}$channels. Thus, voltage-gated $\mathrm{Ca}^{2+}$ channels are opened to promote increased insulin secretion into the blood stream [43] (Figure 1). Melittin also promotes insulin secretion by activating phospholipase $A_{2}$ [44].
The activated phospholipase $\mathrm{A}_{2}$ promotes arachidonic acid production, which, in turn, acts as a calcium transporter into the $\beta$-cells to stimulate insulin secretion [47].

It is also reported that phospholipase $\mathrm{A}_{2}$ has an alternative antidiabetic mode of action by increasing glucose uptake into the adipose tissues rather than increasing insulin secretion. Due to its enzymatic action, it can partially break down the cell membrane of plasmatic lipoproteins [48]. This activity leads to increased glucose transport and lipid uptake into the adipose tissues through partial lyses of adipocyte membranes and binding of a higher number of insulin molecules [49]. Meanwhile, phospholipase $\mathrm{A}_{2}$ also has a higher affinity for the plasmatic lipoproteins, which leads to cytotoxic effects and generation of free fatty acids and lysophospholipids. Thus, circulating cholesterol in HDL is esterified and significantly regulates lipid profiles [50].

Another in vivo study conducted by Kim et al. reported that BV can prevent insulitis and the development of diabetes in NOD mice due to its immune-modulating activities, often attributed to an autoimmune process that damages the pancreatic cells [20]. Their investigations also confirmed that BV injections did not yield any side effects during the experimental period, indicating its safety.

\section{Future Directions}

Since melittin is a small peptide of 26 amino acids, it is often administered subcutaneously, which can lead to several adverse reactions, including local erythema, swelling, tenderness, itching, edema, malaise, flu-like symptoms, and urticaria [15]. Although melittin significantly reduces glucose and cholesterol levels in the bloodstream, its toxicity must be reduced before it can be used as an antidiabetic agent. 
Computational bioinformatics and recombinant technology may be used to produce various modified melittin with high therapeutic effects and minimal toxicity. Further investigation should be carried out to (1) improve the procedure of BV collections without killing the bees, (2) develop melittin extraction methods to allow high yields of BV, and (3) improve the preservation methods of $\mathrm{BV}$ to maintain its efficacy.

\section{Conclusion}

This review article was prepared as a preliminary resource to gather information on the potential of BV, specifically its major active constituent melittin against diabetes mellitus. In diabetes treatment, great consideration is given to lowering blood glucose with various in vitro studies showing that bee venom significantly reduces blood glucose levels via several mechanisms. Nevertheless, there is still lack of adequate in vivo studies done especially using pure melittin from BV. Finally, due to the potential of melittin for reducing blood glucose levels and total cholesterol by several different mechanisms, it is concluded that melittin can have a great impact in the near future in the treatment of diabetes mellitus.

\section{Conflicts of Interest}

The authors confirm that the content of this article has no conflicts of interest.

\section{Authors' Contributions}

Md. Sakib Hossen conceived the ideas for this manuscript and also wrote the manuscript. Dr. Md. Ibrahim Khalil and Dr. Siew Hua Gan reviewed and approved this manuscript.

\section{Acknowledgments}

The authors acknowledge the National Science and Technology (NST) Fellowship (2014/2015) for providing financial support to Mr. Md. Sakib Hossen to pursue his M.S.

\section{References}

[1] P. Vigneri, F. Frasca, L. Sciacca, G. Pandini, and R. Vigneri, "Diabetes and cancer," Endocrine-Related Cancer, vol. 16, no. 4, pp. 1103-1123, 2009.

[2] M. Stolar, "Glycemic control and complications in type 2 diabetes mellitus," American Journal of Medicine, vol. 123, no. 3, pp. S3-S11, 2010.

[3] U. C. S. Yadav, K. Moorthy, and N. Z. Baquer, "Effects of sodium-orthovanadate and Trigonella foenum-graecum seeds on hepatic and renal lipogenic enzymes and lipid profile during alloxan diabetes," Journal of Biosciences, vol. 29, no. 1, pp. 81-91, 2004.

[4] S. Bogdanov, "Bee venom: composition, health, medicine: a review," Bee Product Science, 2015.

[5] G. Lee and H. Bae, "Anti-inflammatory applications of melittin, a major component of bee venom: Detailed mechanism of action and adverse effects," Molecules, vol. 21, no. 5, article no. 616, 2016.

[6] S. Bogdanov, "Royal jelly, bee brood: composition, health, medicine: a review," Lipids, vol. 3, pp. 8-19, 2011.

[7] S. Bogdanov, T. Jurendic, R. Sieber, and P. Gallmann, "Honey for nutrition and health: a review," Journal of the American College of Nutrition, vol. 27, no. 6, pp. 677-689, 2008.

[8] W. F. DeGrado, G. F. Musso, M. Lieber, E. T. Kaiser, and F. J. Kézdy, "Kinetics and mechanism of hemolysis induced by melittin and by a synthetic melittin analogue," Biophysical Journal, vol. 37, no. 1, pp. 329-338, 1982.

[9] G. Gajski, A.-M. Domijan, B. Žegura et al., "Melittin induced cytogenetic damage, oxidative stress and changes in gene expression in human peripheral blood lymphocytes," Toxicon, vol. 110, pp. 56-67, 2016.

[10] A. G. Hegazi, F. A. A. Raboh, N. E. Ramzy, D. M. Shaaban, and D. Y. Khader, "Bee venom and propolis as new treatment modality in patients with localized plaque psoriases," International Research Journal of Medicine and Medical Sciences, vol. 1, pp. 27-33, 2013.

[11] E. Ludyanskii, Apitherapy 1231. Poligrafist, Russia, Vologda, 1994.

[12] B. R. Paull, J. W. Yunginger, and G. J. Gleich, "Melittin: An allergen of honeybee venom," The Journal of Allergy and Clinical Immunology, vol. 59, no. 4, pp. 334-338, 1977.

[13] B. Przybilla, F. Ruëff, A. Walker et al., "Diagnose und Therapie der Bienenund Wespengiftallergie," Allergo Journal, vol. 20, pp. 318-339, 2011.

[14] K. Savilov, "Bee venom: physico-chemical properties. biological and pharmacological effects. use in medical practice," Theoretical and practical basics of apitherapy (Russian), Roszdrav Ryazan, pp. 135-162, 2010.

[15] R. Shimpi, P. Chaudhari, R. Deshmukh, S. Devare, Y. Bagad, and M. Bhurat, A Review: Pharmacotherapeutics of Bee Venom, 2016.

[16] A. K. Sobotka, R. M. Franklin, N. F. Adkinson Jr., M. Valentine, H. Baer, and L. M. Lichtenstein, "Allergy to insect stings. II. Phospholipase A: the major allergen in honeybee venom," The Journal of Allergy and Clinical Immunology, vol. 57, no. 1, pp. 2940, 1976.

[17] D. J. Son, J. W. Lee, Y. H. Lee, H. S. Song, C. K. Lee, and J. T. Hong, "Therapeutic application of anti-arthritis, pain-releasing, and anti-cancer effects of bee venom and its constituent compounds," Pharmacology and Therapeutics, vol. 115, no. 2, pp. 246-270, 2007.

[18] M. T. Tosteson, S. J. Holmes, M. Razin, and D. C. Tosteson, "Melittin lysis of red cells," The Journal of Membrane Biology, vol. 87, no. 1, pp. 35-44, 1985.

[19] N. Urtubey, Apitoxin, from bee venom to apitoxin for medical use, Termas de Rio Grande Santiago del Estero, Argentina, 2005.

[20] J.-Y. Kim, S.-H. Cho, Y.-W. Kim et al., "Effects of BCG, lymphotoxin and bee venom on insulitis and development of IDDM in non-obese diabetic mice," Journal of Korean Medical Science, vol. 14, no. 6, pp. 648-652, 1999.

[21] S. M. Mousavi, S. Imani, S. Haghighi, S. E. Mousavi, and A. Karimi, "Effect of Iranian honey bee (apis mellifera) venom on blood glucose and insulin in diabetic rats," Journal of ArthropodBorne Diseases, vol. 6, no. 2, pp. 136-143, 2012.

[22] S. Prakash and H. R. Bhargava, "Apis cerana bee venom: It's antidiabetic and anti-dandruff activity against Malassezia furfur," World Applied Sciences Journal, vol. 32, no. 3, pp. 343-348, 2014. 
[23] TS. Khulan AM and CH. Chimedragcha, "Effect of Honey Bee Venom (Apis mellifera) on Hyperglycemia and Hyperlipidemia in Alloxan Induced Diabetic Rabbits," Journal of Diabetes Metabolism.6, 2015.

[24] P. S. Koh, B. K. Seo, N. S. Cho, H. S. Park, D. S. Park, and Y. H. Baek, "Clinical effectiveness of bee venom acupuncture and physiotherapy in the treatment of adhesive capsulitis: a randomized controlled trial," Journal of Shoulder and Elbow Surgery, vol. 22, no. 8, pp. 1053-1062, 2013.

[25] J.-W. Park, J.-H. Jeon, J. Yoon et al., "Effects of sweet bee venom pharmacopuncture treatment for chemotherapyinduced peripheral neuropathy: a case series," Integrative Cancer Therapies, vol. 11, no. 2, pp. 166-171, 2012.

[26] B.-K. Seo, J.-H. Lee, W.-S. Sung, E.-M. Song, and D.-J. Jo, "Bee venom acupuncture for the treatment of chronic low back pain: study protocol for a randomized, double-blinded, shamcontrolled trial," Trials, vol. 14, no. 1, article 16, 2013.

[27] B.-C. Shin, J. C. Kong, T.-Y. Park, C.-Y. Yang, K.-W. Kang, and S.-M. Choi, "Bee venom acupuncture for chronic low back pain: A randomised, sham-controlled, triple-blind clinical trial," European Journal of Integrative Medicine, vol. 4, no. 3, pp. e271-e280, 2012.

[28] Y. M. Wong, "Regarding clinical effectiveness of bee venom acupuncture for adhesive capsulitis," Journal of Shoulder and Elbow Surgery, vol. 22, no. 9, p. e19, 2013.

[29] C. E. Dempsey, "The actions of melittin on membranes," BBA-Reviews on Biomembranes, vol. 1031, no. 2, pp. 143-161, 1990.

[30] J. E. Fletcher and M.-S. Jiang, "Possible mechanisms of action of cobra snake venom cardiotoxins and bee venom melittin," Toxicon, vol. 31, no. 6, pp. 669-695, 1993.

[31] G. Gajski and V. Garaj-Vrhovac, "Melittin: A lytic peptide with anticancer properties," Environmental Toxicology and Pharmacology, vol. 36, no. 2, pp. 697-705, 2013.

[32] K. K. Hou, H. Pan, P. H. Schlesinger, and S. A. Wickline, "A role for peptides in overcoming endosomal entrapment in siRNA delivery-a focus on melittin," Biotechnology Advances, vol. 33, no. 6, pp. 931-940, 2015.

[33] H. W. Huang, "Molecular mechanism of antimicrobial peptides: The origin of cooperativity," Biochimica et Biophysica Acta Biomembranes, vol. 1758, no. 9, pp. 1292-1302, 2006.

[34] M. Moreno and E. Giralt, "Three valuable peptides from bee and wasp venoms for therapeutic and biotechnological use: Melittin, apamin and mastoparan," Toxins, vol. 7, no. 4, article no. A020, pp. 1126-1150, 2015.

[35] H. Pan, N. R. Soman, P. H. Schlesinger, G. M. Lanza, and S. A. Wickline, "Cytolytic peptide nanoparticles ('NanoBees') for cancer therapy," Wiley Interdisciplinary Reviews: Nanomedicine and Nanobiotechnology, vol. 3, no. 3, pp. 318-327, 2011.

[36] H. Raghuraman and A. Chattopadhyay, "Melittin: A membrane-active peptide with diverse functions," Bioscience Reports, vol. 27, no. 4-5, pp. 189-223, 2007.

[37] G. Van Den Bogaart, J. V. Guzmán, J. T. Mika, and B. Poolman, "On the mechanism of pore formation by melittin," Journal of Biological Chemistry, vol. 283, no. 49, pp. 33854-33857, 2008.

[38] H. J. Park, S. H. Lee, D. J. Son et al., "Antiarthritic effect of bee venom: Inhibition of inflammation mediator generation by suppression of NF-?B through interaction with the p50 subunit," Arthritis, vol. 50, pp. 3504-3515, 2004.

[39] J. Schmidt and S. Buchmann, Other products of the hive. The Hive and the Honey Bee, Hamilton, Ill, USA, 1992.
[40] B. M. Czarnetzki, T. Thiele, and T. Rosenbach, "Evidence for leukotrienes in animal venoms," The Journal of Allergy and Clinical Immunology, vol. 85, no. 2, pp. 505-509, 1990.

[41] R. Krell, 1996, Value-added products from beekeeping: Food \& Agriculture Org.

[42] E. L. Danneels, M. Van Vaerenbergh, G. Debyser, B. Devreese, and D. C. de Graaf, "Honeybee venom proteome profile of queens and winter bees as determined by a mass spectrometric approach," Toxins, vol. 7, no. 11, pp. 4468-4483, 2015.

[43] N. G. Morgan and W. Montague, "Stimulation of insulin secretion from isolated rat islets of Langerhans by melittin," Bioscience Reports, vol. 4, no. 8, pp. 665-671, 1984.

[44] E. Simonsson, S. Karlsson, and B. Ahrén, "Islet phospholipase A2 activation is potentiated in insulin resistant mice," Biochemical and Biophysical Research Communications, vol. 272, no. 2, pp. 539-543, 2000.

[45] S. Heisler, "Phospholipase A2 activation by melittin causes amylase release from exocrine pancreas," Canadian Journal of Physiology and Pharmacology, vol. 67, no. 5, pp. 411-416, 1989.

[46] H. J. Park, H. J. Lee, M. S. Choi et al., "JNK pathway is involved in the inhibition of inflammatory target gene expression and NFkappaB activation by melittin," Journal of Inflammation, vol. 5, article 7, 2008.

[47] W. Y. Fujimoto and S. A. Metz, "Phasic effects of glucose, phospholipase a2, and lysophospholipids on insulin secretion," Endocrinology, vol. 120, no. 5, pp. 1750-1757, 1987.

[48] J. Singh and R. Ranganathan, "Quantitation of lysolipids, fatty acids, and phospholipase A2 activity and correlation with membrane polarity," Journal of Lipid Research, vol. 53, no. 9, pp. 1993-2001, 2012.

[49] T. Wieringa, G. de Bruin, W. P. M. van Meerwijk, and H. M. J. Krans, "Effect of purified phospholipases on glucose transport, insulin binding, and insulin action in isolated rat adipocytes," Cell Biochemistry and Biophysics, vol. 4, no. 4, pp. 261-271, 1982.

[50] C. Guillaume, C. Calzada, M. Lagarde, J. Schrével, and C. Deregnaucourt, "Interplay between lipoproteins and bee venom phospholipase A2 in relation to their anti-plasmodium toxicity," Journal of Lipid Research, vol. 47, no. 7, pp. 1493-1506, 2006. 

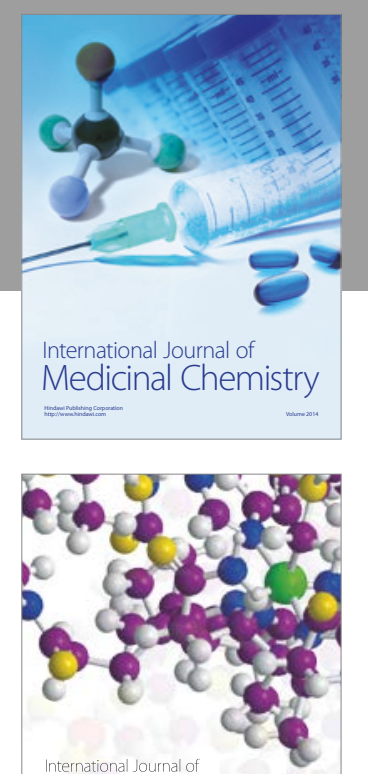

Carbohydrate Chemistry

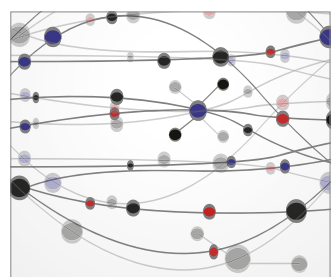

The Scientific World Journal
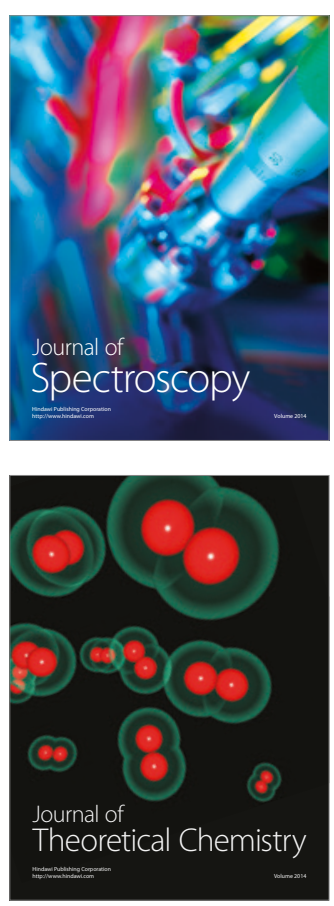
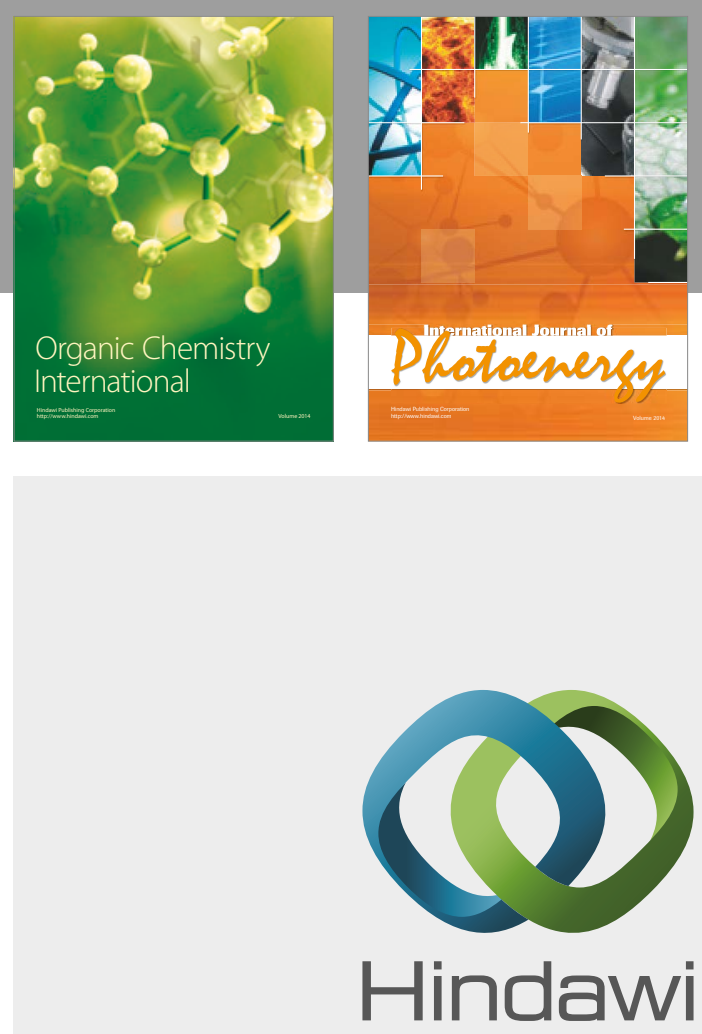

Submit your manuscripts at

https://www.hindawi.com

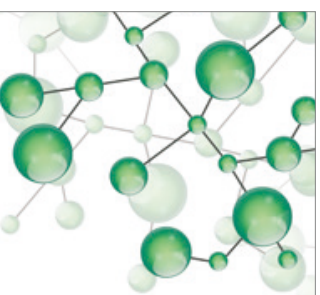

International Journal of

Inorganic Chemistry

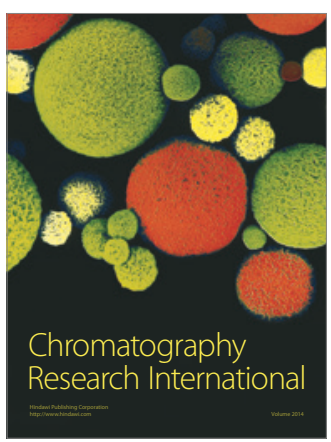

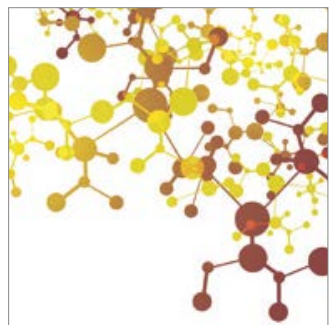

Applied Chemistry
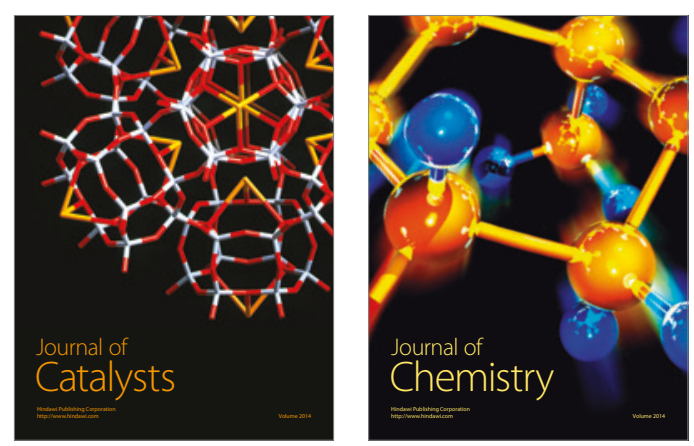
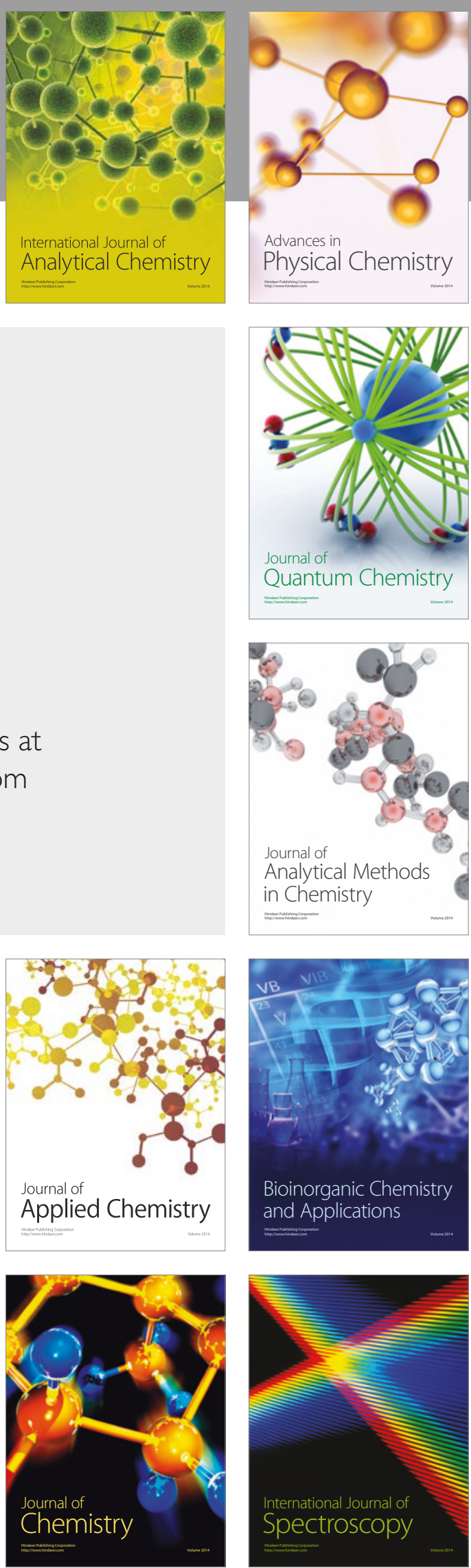